\title{
Kavramsal Bağlamı ve Olası Tartışma Alanlarıyla Psikolojik Sözleşme: Bir Gözden Geçirme Çalışması
}

\author{
Mustafa Kemal TOPCU, H.Nejat BASIM*
}

Kavramsal Bağlamı ve Olası Tartışma Alanlarıyla Psikolojik Sözleşme: Bir Gözden Geçirme Çalışması

Özet

Çalışma hayatında işgücü verimliliği klasik yönetim anlayışının üzerinde durduğu önemli alanlardan birisi olmuştur. Teknolojik değişim, küreselleşme, kalite anlayışı, sürdürülebilirlik ve sosyal inovasyon yönetim anlayışını değiştirmiş ve işletmelerin hem iç hem dış çevresini şekillendirmiştir. Bu süreçte işgücü giderek daha da önem kazanmış ve değişen endüstriyel ilişkileri açıklamak için farklı kuram, yöntem ve araçlar kullanılmıştır. Bu bağlamda, çalışanların tutum ve davranışlarının belirleyicisi olan psikolojik sözleşme, işgören-işveren ilişkisini açıklamakta da faydalı olmaktadır. Ancak, çalışanların tutum ve davranışlarının anlaşılabilmesi için onların algılarının bilinmesine ihtiyaç bulunmaktadır. Psikolojik sözleşme yöneticilere bu bakış açısını sunabilen bir araç, bir yöntem niteliği taşımaktadır. Bu çerçevede, bu çalışmada psikolojik sözleşmenin tanımı, kapsamı, boyutları ve gelişimi kuramsal yaklaşımlar bağlamında ele alınmakta, kuramsal eleştiriler incelenmekte ve gelecekteki çalışmalar için bazı önerilerde bulunulmaktadır.

Anahtar Kelimeler: Psikolojik Sözleşme, Endüstriyel ilişkiler, Pozitif Psikoloji, îhlal Algısı
A Review on Psychological Contract with Concepts and Possible Discussion Areas

Abstract

Labor producitvity is one of issues that classic management approach attaches great importance. Technological change, globalization, quality perception, sustainability, and social innovation made changes on management concept and formed both internal and external environment of enterprises. Meanwhile, stress on workforce has been ever grown. During this process, a great variety of theories, methodologies and tools are employed to explain changing industrial relations. To this end, pscyhological contract as a determinant of organizational attitudes and behaviors is also useful to explain employer-employee relationship. However, perception of employees are to be understood to conceive organizational attitudes and behaviors. Psychological contract is a tool, a methodology to provide this perspective to managers. Toward this end, this study reviews psychological contract concept, context, factors and evolution with a theoretical approach, evaluates theoretical critics, and makes some recommendations for future research.

Key Words: Psychological Contract, Industrial Relations, Positive Psychology, Violation

\section{Giriş}

Psikolojik sözleşme konusuna olan ilgi uluslararası yazında özellikle son otuz yıl içerisinde artmıştır. 1960'lardaki tanımlama çalışmalarından yirmi yıl sonra aradaki boşluğu dolduracak görgül çaIışmalar yapılmaya başlanmıştır. Ulusal alanyazın bağlamında da psikolojik sözleşme son on yıl içerisinde telaffuz edilmeye başlanmış ve bazı çalışmalara konu edilmiştir. Ne var ki, psikolojik sözleşme kavramını bütüncül bir bakış açısı ile ele alan, alanın nereye doğru gittiğini tartışan, muhtemel araş-

\footnotetext{
* Mustafa Kemal TOPCU, Dr., Ankara Sanayi Odası, mustafatopcu@aso.org.tr ; H.Nejat BASIM, Prof.Dr., Başkent Üniversitesi, İktisadi İdari Bilimler Fakültesi, n.basim@gmail.com
} 
tırma alanlarını ortaya koyan bir çalışmaya rastlanılmamıştır. Bu nedenle, psikolojik sözleşme literatürüne bütüncül bir yaklaşımla bileşenleri, özellikleri, öncülleri ve sonuçları açısından bir gözden geçirme niteliği taşıyan bu çalışmanın araştırmacı ve uygulamacılara ışık tutması beklenmektedir.

Günümüz psikolojik sözleşme yaklaşımı, işverenin kendisine yönelteceği “personel ne ister?” sorusunda kendini göstermektedir. Çalışanlardan yüksek performans elde etme, çalışanların bağ|lIıklarını artırma, sadakat, ekstra gayret, düşük seviyede devamsızlık ve yüksek verimlilik almak isteyen örgütler "personel ne ister?" sorusuna cevap aramak durumundadır. Patrick (2008) bu sorunun net cevabının psikolojik sözleşmeden geçtiğini belirtmektedir.

Psikolojik sözleşmeden bahsederken işveren-işgören ilişkisini genel çerçevesinden ele almak gerekmektedir. Endüstriyel ilişkilerin işveren odağından işgören odağına yöneldiğini belirtmek yanlış olmayacaktır. İşgörenin bireysel gelişimini ön plana çıkaran bir anlayışın hakim olduğu bu yaklaşımda işverenin güvenceden ziyade katma değer yaratacak bir ödül sistemi kurması beklenmektedir. Diğer taraftan ise işgörenden üretken davranışlar ve özellikle yaratıc fikirlerle yenilikçi davranışlar sergilemesi istenmektedir. Böylelikle, psikolojik sözleşmeler işgörene kontrol ve iş güvencesi duyguları verirken, işvereni de işgöreni sürekli gözetmek zahmetinden kurtarmaktadır (Aselage ve Eisenberger, 2003, s. 495).

İşveren-işgören ilişkisindeki bu yeni yaklaşımın temelinde işyerlerinin küçülmesi, işgücünün esnekliği ve bölünmesi, değişime direnilememesi, kadın istihdamının artması ve iş-aile dengesinin önem kazanması sayılabilir (Porter ve Lewis, 1998). Değişen çalışma koşulları, işgören-işveren arasındaki ilişkinin seyri ve regülasyonlara uyum çerçevesinde, daha belirsiz bir ortamda cereyan edeceği öngörülen psikolojik sözleşmenin örgütsel tutum ve davranışların odağında yer aldığı görülmektedir. Değişen endüstriyel ilişkiler bağlamında bireyselliğin ön plana çıktığı, fırsat eşitliğinin vazgeçilmez olduğu görülmektedir. Porter ve Lewis (1998) bu değişimi yorumlarken, sendikalaşmanın yerini bireyselliğe terk etmeye, yönetimin kontrol fonksiyonunu keşfetmeye başladığına ve insan kaynakları yönetiminin stratejik önem kazandığına vurgu yapmaktadır.

Endüstriyel ilişkiler bağlamında çalışma koşullarındaki değişen anlayışla birlikte örgütsel tutum ve davranışların belirleyicisi olan psikolojik sözleşmenin ayrıca ele alınma ihtiyacı daha da belirginleşmektedir. Bu amaçla hazırlanan bu çalışmada psikolojik sözleşme kavramının boyutları, türleri, kuramsal gelişimi, öncül ve sonuçları ile birlikte kavrama yöneltilen kuramsal eleştiriler ve muhtemel çalışma alanları incelenmektedir.

\section{Psikolojik Sözleşme Kavramı}

\subsection{Psikolojik Sözleşmenin Tanımı ve Kapsamı}

Psikolojik sözleşmeler; algılar, beklentiler, inançlar, vaatler ve yükümlülükler gibi soyut terimlerle ifade edilmeye çalışımış, ancak somut bir tanıma kavuşturulamamıştır. Endüstri ve sektör fakIııkları tanımlamayı zorlaştırdığı gibi işveren-işgören bakış açısı bu zorluk derecesini daha da artırmıştir. 
Bu çerçevede psikolojik sözleşme kavramının tartışılması ve çalışma bağlamında tanımının ortaya konulması faydalı olacaktır. Psikolojik sözleşmenin ne bir kuram ne de bir ölçme metodu olmadığı ifade edilebilir. Çünkü psikolojik sözleşme hukuki bir metafora dayanan hipotetik bir çıkarımdır (Guest, 1998, s. 650). Yazılı bir iş sözleşmesinden çok daha öznel, beklentilerin ötesinde çok daha geniş kapsamlıdır. Schein (1980) örgütsel psikoloji alanına yaptığı katkıların içerisinde psikolojik sözleşme kavramına yer vermiş ve yazılı olmayan beklentilerin dinamizmi olduğunu belirtmiştir. Benzer şekilde Schein (1978) başka bir çalışmasında psikolojik sözleşmeyi işgören ve örgüt arasındaki yazılı olmayan karşııkı beklentiler seti şeklinde tarif etmiştir. Başka bir ifade ile psikolojik sözleşmeler iş ilişkisi ile ilgili hak ve yükümlülüklere ilişkin varsayımlardan oluşmaktadır (Nicholson ve Johns, 1985, s. 400).

Diğer taraftan Rousseau (1989) psikolojik sözleşmenin karşılıklıık algısını birey seviyesine indirgemiş ve çalışanın işle ilgili ilişkilerinde karşılıklı yükümlülükler konusundaki algıları ve beklentileri şeklinde tanımlamıştır. Rousseau (1995) psikolojik sözleşmeye, bireyler ile örgüt arasındaki mübadele kapsamında örgüt tarafından şekillendirilen bireysel inançlar şeklinde de bir tanım getirmektedir. Zaten bireysel algılarda farklıık olacağından öznellik sözleşmenin temelini oluşturmaktadır (Anderson ve Schalk, 1998). Bu sebeple, zaman içerisinde şartların değişimi ile birlikte sözleşmede de değişiklikler yaşanabilmektedir. Algılarda değişiklik olabileceği gibi örgütsel ve çevresel faktörlerde de değişim söz konusu olabilir. Örneğin amirin değişmesi işgörenin psikolojik sözleşmesini gözden geçirmesine neden olabilir. İşgörenin kariyerinin her aşamasında psikolojik sözleşme gözden geçirilebileceği gibi birey her iş değiştirdiğinde de sözleşmesini yenilemektedir (Nelson ve Quick, 1999, s. 514).

Bu sebeple, Herriot ve Pemberton (1995) psikolojik sözleşmeye bir süreç olarak yaklaşmakta, psikolojik sözleşmenin çalışanlar ve örgüt arasında geliştirilen iş ilişkisindeki yükümlülüklerin algılanmasından ibaret olduğunu belirtmekte ve psikolojik sözleşmenin bu algılayışların varmak istediği süreç olduğunu savunmaktadır.

Bu bakış açısıyla işe yeni başlayan işgörenlerin psikolojik sözleşmeleri; kariyer fırsatları, maddi ödüller, zengin iş içeriği gibi işveren tarafından sunulan sözler ile bunun karşılığında performans, ekstra-rol davranışı, esneklik ve sadakat gibi kendilerinin sağlamaya söz verdikleri durumları içermektedir. Psikolojik sözleşme, bu çerçevede, işe yeni başlayan işgörenin anlama, yorumlama ve yeni çevrelerine tepki vermeleri için anlam kazandırma süreci olarak da düşünülebilir. Bu süreç yeni gelen kişinin beklentileri ile gerçekleri karşılaştırmasına olanak tanımaktadır (Rousseau, 2001).

Bunlarla birlikte çalışanlar psikolojik sözleşmelerini üç yöntemle geliştirmektedir (Rousseau, 1995). illk yöntem diğer çalışanların ifadelerine bağlı olarak geliştirmektir. İş görüşmelerinde çalışanlar personel temin görevlisi veya mülakatta bulunanlar tarafından açık bir şekilde veya zımni olarak yapılan açıklamalar sonucunda taahhüt algısına kapılabilir. Çalışmaya başlandıktan sonra, diğer çalışanlar veya amirler, işveren-işgören arasındaki yükümlülükler hakkındaki görüşlerini paylaşarak algılara katkıda bulunabilir. İkincisi çalışan diğer çalışan ile işveren arasındaki ilişkileri gözlemleyerek fikir sahibi olabilir. Üçüncüsü örgütlerin ücret yönetimi, performans değerlendirmeleri, örgütsel kültür, 
kılavuz ve misyon ifadeleri gibi yazılı olan resmi prosedürleri de psikolojik sözleşmelerin oluşumuna etki edebilir. Kısacası, çalışanlar beklentilerini diğer çalışanları gözlemleyerek ve insan kaynakları uygulamalarını yorumlayarak oluşturmaktadır (Freese ve Schalk, 1996).

Literatürde psikolojik sözleşmenin içeriği ile ilgili farklılıklar olduğu görülmektedir. Guest (1998) de içerikle ilgili çalışmaların giderek zenginleştiğine işaret etmektedir. Bu çalışmaları psikolojik sözleşme yazınına katkıda bulunan temel araştırmacıların yönlendirdiği görülmektedir. Son dönemde Rousseau (2000)'nun kuramsal çalışmalarda öncü olduğu ifade edilebilir.

Psikolojik sözleşme araştırmaları yakın zamana dek karşıııklı beklentiler üzerine odaklanmış iken (Schein, 1980), daha sonraları yapılan çalışmalarda ilgi daha çok yükümlülüklere kaymıştır (Rousseau, 1990; Rousseau ve MacLean Parks, 1993). Fakat yükümlülük ve beklenti terimlerinin de çalışmalarda birbirinin yerine kullanıldığı görülmektedir. Zaten fiil yerine getirildiği sürece bunun bir beklenti veya yükümlülük olmasının nasıl bir fark yaratacağı da muğlâk kalmaktadır (Thomas ve Anderson, 1998).

Psikolojik sözleşme, sübjektif inançları ve taraflar arasındaki değişimi intiva etmektedir. Ancak hangi konuların bu içerikte yer aldığını ifade etmek oldukça güçtür. Örneğin; Cavanaugh ve Noe (1999)'ya göre, psikolojik sözleşme iş güvencesi, performans gerekleri, eğitim, ücretlendirme ve kariyer yönetimi konularına ilişkin algı ve beklentileri kapsayabilir.

Diğer taraftan, Rousseau ve Tijoriwala (1998, s. 684) psikolojik sözleşmenin kapsamına ilişkin değerlendirmeleri; içerik odaklı, özellik odaklı ve değerlendirme odaklı olmak üzere üç başlık altında toplamaktadır.

İçerik odaklı değerlendirmede psikolojik sözleşme iş güvencesi temelinde bireysel olabileceği gibi kariyer yönetimine dayalı daha geniş kapsamlı da olabilir. Bu açıdan sözleşme içeriğinin bütüncül değerlendirilmesi için uygun ölçme modellerine intiyaç duyulmaktadır.

Özellik odaklı değerlendirmeden kastedilmek istenen ise psikolojik sözleşmeleri bazı boyut veya karakteristiklere göre değerlendirmektir. Sözleşmenin içeriği iş güvencesi veya kariyer gelişimi ile nitelendirildiği zaman özellikleri açııından farklııklar oluşmaktadır. Sözleşmeleri yazılı olmayan, açık uçlu gibi sıfatlarla belirtmek daha uygun olmaktadır. Ancak, bu konu üzerinde yeterli seviyede araştırma bulunmamaktadır.

Değerlendirme odaklı yaklaşım içerisinde de tatmin olma, değişme veya algılanan ihlalin derecesi ile ilgili çalışmalar yer almaktadır. Beklentiler sonucu oluşan duygular farklılaşmaktadır. Böylelikle işgören tutum ve davranışlarını gözden geçirerek olumlu veya olumsuz yönde hareket etmektedir. Dinamizmden dolayı bu değerlendirmeler sürekli niteliktedir.

Diğer taraftan psikolojik sözleşme hem kişisel hem de genel bakış açısını gerekli kılmaktadır (Morrison ve Robinson, 1997). Her ne kadar bireysel algılar ve değerlendirmeler söz konusu olsa da 
özellikle örgüt iklimi üzerine yapılan araştırmalar bazı konuların örgütsel kapsama değin genelleştirilebileceğini göstermiştir (Schneider, 1990). Örnek olarak, ödüller, kariyer seçenekleri, lider-üye değişimleri verilebilir. Temel varsayım, bireysel değerlendirmelerin zamanla kabul gören genel değerlendirmeler olacağı yönündedir.

\subsection{Psikolojik Sözleşmenin Boyutları}

Araştırmacılar psikolojik sözleşmenin çok boyutlu yapısının açıklanmaya çalışıldığına dikkat çekmektedir. Rousseau ve MacLean Parks (1993) psikolojik sözleşmeyi istikrar, kapsam, somutluk, odak ve vade olmak üzere beş boyutta incelemektedir. Sels ve arkadaşları (2004) boyutları tek tek ele alarak aşağıdaki gibi açıklamaya çalışmaktadır.

Soyut-somut ikileminde somutluk boyutu; işgörenin sözleşme şartlarını açıkça tanımlanmış, belirtilmiş ve üçüncü şahıslar tarafından gözlenebilir olarak algılama derecesidir. Somut ilişkiler, hukuk kuralları, örgütün yazıı dokümanları ve yazılı iş sözleşmelerinden kaynaklanmaktadır. Belirli iş tanımları, açıkça ifade edilmiş performans veya değerlendirme kriterleri somut ilişkileri şekillendirmektedir. Soyut ilişkiler ise güvene dayalıdır ve geniş rol tanımından oluşmaktadır.

Diğer bir boyut olan kapsamdan kasıt ise ilişkinin sınırlarıdır. Psikolojik sözleşmeler dar veya geniş kapsamlı olabilmektedir. Yani iş hayatı ile sosyal hayat ayrımı, ilişkinin ekonomik çıkarlara dayalı olması, yapılan işin bir araç olarak algılanması, çok az ekstra rol davranış sergilenmesi, düşük katılım seviyesine sahip olunması dar kapsamı belirtmektedir. İşverenin işgörenin aile hayatı ile ilgilenmesi, ekstra rol davranışları, işverene adanmışıık ve aile içi işe alımlar geniş kapsamlılık içerisinde değerlendirilmektedir.

Psikolojik sözleşme şartlarının zaman içerisinde değişip değişmeme durumu başka bir boyut olan sözleşmenin istikrarını göstermektedir. Bu boyut sözleşme şartlarının tekrar müzakere ihtiyacı olmadan değişebilme ve gelişebilme durumunu izah etmektedir. Durağan sözleşmeden kastedilen sözleşme kurallarına sıkı sıkıya bağlıık, çok az esnek davranış sergileme ve belirsizliğe tahammül gösterememedir. Esnek ilişkilerde ise değişime ve belirsizliğe yüksek tolerans vardır ve sözleşme şartları değişken yapıdadır.

Psikolojik sözleşmenin vadesi algılanan süresi kadardır. Geçici işgörenler için uzun vadeli sözleşmeler zaten mevzu bahis edilememektedir. Uzun bir süreli ilişkide; iş güvencesi, kapalı iş gücü piyasası, kıdem esasına dayalı terfi ve çok az dış mobilite söz konusudur. Kısa süreli ilişkinin göstergeleri arasında; isteğe bağlı işe alma, emek mobilitesi, sınırlı sayıda açık uçlu sözleşmeler, istihdam edilirlik ve sınırsız kariyer seçenekleri sayılabilir.

\section{3. Psikolojik Sözleşme Türleri}

Sözleşmeler birey arasında veya grup içerisinde olma durumuna göre ve toplum tarafından algılanış şekline göre tasnif edilebilmektedir. Birey taraf ise psikolojik, grup taraf ise normatif sözleşmeden bahsedilmektedir. Sözleşmelerde bireyin algısı söz konusu ise zımni ve toplumun algısı söz konusu ise sosyal sözleşmeden bahsetmek mümkündür. 
Psikolojik sözleşmeleri algılanış şekillerine göre de sınıflandırmak söz konusudur. Ancak bu konuda farklı görüşler bulunmaktadır. Anderson ve Schalk (1998) ve Patrick (2008) dört çeşit sözleşmeden bahsederken, Thomas ve Anderson (1998) ve Rousseau ve Wade-Benzoni (1994) sadece iki sözleşme türü olduğunu belirtmektedir. Sözleşme türleri nasıl isimlendirilirse isimlendirilsin temel ayrım vadeleri ve çalışanların katılım seviyeleridir (Rousseau ve Tijoriwala, 1998).

Patrick (2008) sözleşmeleri geleneksel, ilişkisel, geçiş ve dengeli olmak üzere dört grupta tasnif etmektedir. Dengeli sözleşmeler açık uçludur. Ilişkiye dayanan istihdam söz konusu olup, zamanla değişen performans kriterlerini barındırmaktadır. Geçiş sözleşmeleri; sözleşmeler setinden oluşup, gelecek için istihdam garantisini kapsamamakta, açık performans talepleri ve durumsal teşvikler içermemektedir.

Rousseau ve Wade-Benzoni (1994, s. 466) tarafından belirtildiği gibi sözleşmeleri iki ana ayrımda ele almak yeterlidir. Bireyin taraf olduğu psikolojik sözleşmeler geleneksel ve ilişkisel olmak üzere sınıflandırılabilir (Thomas ve Anderson, 1998). Örgütle bütünleşmek isteyen ve kurum içerisinde kariyer planları yapan bir işgören kapsamlı bir psikolojik sözleşme arayışına girerken, kısa süreli bir ilişki düşünen işgören sınırı bir sözleşme geliştirecektir. Bu ayrıma göre geleneksel veya işlemsel sözleşmelerde işgörenin sorumlulukları arasında işgöreni işten ayırmadan belli bir süre önce haber verme, transferleri kabul etme, rakiplerden herhangi birisini desteklememe, örgüte özel bilgiyi saklı tutma ve işyerinde en az iki yıl çalışma sayılabilir. İşverenin de işgörene hemen ilerleme olanakları sunması, yüksek ücret ödemesi ve performansa göre ödeme yapması beklenmektedir.

Geleneksel sözleşmeler, kısa vadeli tamamen ekonomik veya materyalist düşünceye dayanan ve tarafların kısıtlı katılımına müsaade eden bir sözleşme tipidir. Geleneksel sözleşmeler maddi kaynakların mübadelesine dayalı sözleşme türü olarak özetlenebilir. Bu açıdan geleneksel sözleşmeler, sınırlı bir süreyi kapsayan ve performans kriterleri çok iyi tanımlanmış sözleşmelerdir. Bu tür sözleşmelerde temel husus örgütün iş görenin hizmetlerine karşlık ödemede bulunmasıdır.

Geleneksel sözleşmenin iş görenin davranışlarını olumsuz etkileme ihtimali daha yüksektir (De Cuyper, 2008). Rousseau ve Tijoriwala (1998) işverene duyulan güven ile geleneksel sözleşme arasındaki ilişkinin negatif yönlü olduğunu ortaya koymuştur. Bu da örgütsel bağlılık ve örgütsel vatandaşlık davranışlarını olumsuz etkileyerek, iş tatminsizliği yaşanmasına sebep olabilmektedir.

ilişkisel sözleşmeler, açık uçlu üyelikler için söz konusudur ve adanmış üyeliğe bağlı kesin tanımı olmayan performans kriterlerini barındırmaktadır. ilişkisel psikolojik sözleşmede işgörenin fazla mesai yapması, örgüte sadık olması ve ekstra-rol davranışı göstermesi beklenirken, işverenin de iş görene eğitim, uzun dönem iş garantisi, kariyer geliştirme imkanı ve kişisel sorunlarda destek sağlaması beklenmektedir. İlişkisel sözleşmede bireysel gelişim imkanı, aidiyet ve saygınlık ön planda tutulmaktadır (Purvis ve Cropley, 2003, s. 109).

ilişkisel sözleşmeler uzun vadeli, geniş kapsamlı, örgütün büyümesi bakımından veya birey için iş güvencesi açısından ekonomik dürtülerden ziyade sadakate bağlı sözleşme tipidir (Morrison ve 
Robinson, 1997; Rousseau ve McLean Parks, 1993). ilişkisel sözleşmede ana unsur çalışanın örgütsel bağ|ıık derecesidir. ìlişkisel sözleşmeler sosyal mübadele kuramında yer aldığı gibi güven esasının üzerine inşa edilmektedir (Arnold, 1996, s. 513). iliş̧kisel sözleşmelerin açık uçlu olduğu ve sosyoduygusal kaynakların değişimine dayandığı görülmektedir.

Özetle, geleneksel psikolojik sözleşmeler daha çok belirlenmiş, spesifik, kısa vadeli, maddi tatmin ile ilişkilendirilirken, ilişkisel olanlar daha geniş, uzun vadeli, adanmışlık ve bağlılık gibi sosyo-duygusal tatmin ile ilgilidir. ilişkisel sözleşmelerde işgören açısından yetenek ve kariyer yönetimi, işveren açısından eğitim ve geliştirme ön plana çıkmaktadır (Rousseau ve Wade-Benzoni, 1994, s. 466).

Psikolojik sözleşmelerin neredeyse tamamının ekonomik odaklı olduğu kabul edilmektedir (De Cuyper, 2008). Kısacası halihazırda psikolojik sözleşmelerin tamamının geleneksel tarzda olduğu ifade edilebilir. Sözleşmelerin farklılık gösterdiği nokta işveren ile işgören arasındaki ilişkinin içeriğidir. Güncel olarak istihdam süresi ve performans kriterleri sözleşmeleri belirlemektedir (Rousseau ve Wade-Benzoni, 1994, s. 466). Diğer taraftan henüz ampirik olarak test edilmemişse de teorik olarak bazı konular her iki sözleşme türünün de kapsamındadır. Örneğin yüksek performansa yüksek ücret ödenmesi geleneksel bir sözleşme yaklaşımı olsa da işveren-işgören arasındaki ilişki uzun süreli bir ilişkiye dönüşebilir (Arnold, 1996, s. 513).

\section{Psikolojik Sözleşme Yazınındaki Kuramsal Gelişim}

Argyris (1960), Levinson, Price, Munden, Mandl ve Sooley (1962), Schein (1965) ve Rousseau $(1989,1995)$ psikolojik sözleşme kavramına ilişkin temel esasları geliştirmiştir (Zhao ve ark., 2007, s. 648). Ancak, Coyle-Shapiro ve Kessler (2002, s. 72) psikolojik sözleşmenin kavramsal köklerini Barnard (1938)'in eşitlik teorisine kadar götürmektedir. Diğer taraftan zımnen de olsa March ve Simon (1958) tarafından geliştirilen teşvik-katkı modelinde psikolojik sözleşmeden bahsedildiği görülmektedir. Benzer şekilde Homans (1961) tarafından da sosyal mübadele teorisinde psikolojik sözleşme kavramına yer verilmektedir.

Ancak, psikolojik sözleşme terimine ilk olarak Argyris (1960) tarafından dikkat çekildiği görülmektedir. Araştırmacı iki ayrı fabrikada işgören ve ustabaşılar ile yapılan görüşmelerin sonucunda elde edilen veriler yardımıyla durum analizi yapmıştır. İşveren ile işgören arasındaki ilişkiyi tarif etmek için "psikolojik iş sözleşmesi" terimini tercih etmiştir. Üretim hattında çalışan işgören ile ustabaşı arasındaki ilişkide, ustabaşının pasif liderlik sergilemesi halinde işgörenin daha fazla üretebileceği düşüncesini geliştirdiğini fark etmiştir. Buradan yola çıkarak, işgören ile ilk amiri arasında gelişen ilişkinin hipotetize edilebileceğini vurgulamıştır. Ve ustabaşı çalışanın gayri resmî kültürünü oluşturan normlara saygı duyar ve müsaade ederse (işgörenlere karışmama, ücretlerin zamanında ödenmesini sağlama ve iş güvencesi sağlanması gibi), çalışanın daha üretken olacağı şeklinde bir hipotez geliştirmiştir.

Argyris (1960) psikolojik sözleşme terimini açıkça kullanmadığından, tanımını yapmadığından, Levinson (1962) bu kavramın babası sayılmaktadır. Levinson bir elektrik şirketinde yaptığı örnek olay çalışmasında yazılı olmayan sözleşme şeklinden bahsetmektedir. Araştırmacıya göre, psikolojik söz- 
leşme örgüt ile çalışan arasındaki karşılıkı beklentilerin toplamıdır. İşveren ile işgören ilişkisine öncüllük eden örgüt ile çalışan arasında kapalı ve ifade edilmeyen beklentilere işaret edilmektedir. Ücretlendirme ile ilgili olanlar gibi bazı beklentiler daha somut iken, uzun vadede terfi imkânları gibi olanlar daha dolaylıdır.

Kotter (1973) tarafından psikolojik sözleşmenin geçerliği hem işverenler üzerinde hem de işgörenler üzerinde beklentileri tespit edilerek test edilmiştir. Araştırmacı ayrıca beklentiler arasındaki uyumsuzlukların çözüm yollarına ulaşabilmek için de çalıştaylar düzenlemiştir.

Öte yandan, Schein $(1965,1980)$ insan kaynakları uygulamaları açısından psikolojik sözleşmeleri ön plana çıkarmıştır. Araştırmacı bir örgütte bulunanlar arasında sürekli var olan yazılı olmayan beklentilerden bahsetmekte ve birey ile örgüt seviyesinde ayrı ayrı tespitlerde bulunmaktadır.

Psikolojik sözleşme kavramının gelişimine katkıda bulunan araştırmacılardan Herriott ve Pemberton (1995) ise işveren-işgören ilişkilerinin boyutunu ve ilişkilerde birbirlerine sundukları algılayışları tanımlamaktadır.

Incelemelerin hepsinde ortak olan yan, işgören ile işveren arasında bir ilişki mübadelesi olmasıdır. Mütekabiliyet ya da karşılıklıık ilkesi psikolojik sözleşme teorisinin temel açıklayıcı kavramsal unsurudur. Psikolojik sözleşme araştırmalarının esasını işverenin davranışlarına karşııık işgörenin nasıl davrandığı oluşturmaktadır (Coyle-Shapiro ve Kessler, 2002, s. 70).

Bu bağlamda mütekabiliyet kişiler arası ilişkilerin de başlangıcını teşkil etmektedir (Aselage ve Eisenberger, 2003, s. 491). Ancak Arnold (1996) mütekabiliyetin derecesinin ne olacağını ve nereye kadar karşııklı olunacağını sorgularken, Rousseau (1990) bu argümanı destekleyici mahiyette mütekabiliyetin gerekli koşul olmadığını öne sürmektedir.

Mütekabiliyet, çalışan tutum ve davranışlarının anlaşıması için örgütsel araştırmalarda kullanılan bir yöntemdir (Coyle-Shapiro ve Kessler, 2002). Mütekabiliyeti esasen Blau (1964) açıklamaya çalışmıştır. Araştırmacıya göre ilişkilerde hep bir denge arayışı mevcuttur. Ne zaman denge bozulsa yeniden dengeye getirme çabası görülmektedir. Mütekabiliyette ana düşünce bir söz verilmesi ve karşılığında bir fayda elde edilmesidir. Gouldner (1960) mütekabiliyeti iki veya daha fazla birim arasında karşılıklı fayda değişimi şeklinde nitelendirmektedir. Anlık bir faaliyet olmadığı gibi hem geçmişi hem de geleceği kapsamaktadır.

Mütekabiliyete dayalı bu mübadeleyi açıklayan üç model "Temel Sosyal Yapıların Sosyal Değişimi Teorisi", "Teşvik-Katkı Modeli" ve "Eşitlik Modeli"dir. Modellerin üçünde de ilişki mübadelesi söz konusudur ve beklentiler ve yükümlülüklerin oluşması gerekmektedir.

Örgütsel davranış bağlamında sosyal mübadele kuramı çalışanların motivasyonunu ve örgütsel hedeflere ulaşmada motivasyonun rolünü anlamaya yardımcı olmaktadır (Aselage ve Eisenberger, 2003 , s. 492). Sosyal mübadele kuramı, bireylerin diğerleriyle bir fayda elde etmek maksadıyla ilişki kurduklarını belirtmektedir. Böylelikle karşılıklı yükümlülükler kapsamında işveren-işgören ilişkisinin 
temeli de anlaşılabilmektedir. Coyle-Shapiro ve Kessler (2002, s. 72) psikolojik sözleşme araştırmalarının sosyal mübadele yaklaşımına katkı sağladığını belirtmiş ve bu kurama düşünsel boyutu kazandırdığından bahsetmiştir.

Taraflar arasında mübadele edilen kaynaklar, göndericinin kimliğine bağlı olabilir veya olmayabilir (Aselage ve Eisenberger, 2003, s. 491). Hatta bu kapsamdaki bazı kaynaklar saygı ve karşılıklı anlayış gibi sosyo-duygusal da olabilir. Blau (1964) da güçlü kişiler arası ilişkilerin sosyo-duygusal kaynakların karşılıklı değişimiyle gelişebileceğini belirtmiştir.

Sosyal mübadele kuramına göre örgütsel ve sosyo-duygusal kaynaklar bağlamında daha fazla değere kavuşturulan çalışan mütekabiliyet doğrultusunda kendisini tanımlı veya tanımsız iş davranışlarında yüksek performans sergileme zorunluluğunda hissederek, örgütün hedeflerine ulaşmasına katkı sağlayabilecektir (Aselage ve Eisenberger, 2003, s. 492). Taraflar arasındaki ilişki kaynaklara olan bağımlılık derecesine göre ilerleme gösterebilmektedir.

Sosyal mübadele kuramı bağlamında psikolojik sözleşmelerin karşılıklı yükümlülükler doğurduğu ifade edilebilir. Örgütler tarafından kendilerine verilen taahhütler ve bunlara karşı geliştirilecek davranışlar çerçevesinde çalışanlar psikolojik sözleşmelerini şekillendirmektedir. Psikolojik sözleşmede aradaki sosyo-duygusal bağ çalışana verilen sözlerin çeşitleri, karşılığında beklenen yükümlülükler ve sözlerin yerine getirilme derecesine bağlıdır (Rousseau, 1995, 1990).

Aselage ve Eisenberger (2003, s. 498) tarafından belirtildiği gibi sosyal mübadele teorisine göre birey kendi yükümlülüklerini nitelendirebilmek için öncelikle karşı tarafın sağladığı kaynağın değerini belirlemektedir. Bu çerçevede çalışanların motivasyon eksiklikleri, tatminsizlikler ve düşük performansları psikolojik sözleşmeler kapsamında yerine getirilmeyen işveren yükümlülüklerine bağlanabilir (Aselage ve Eisenberger, 2003, s. 492).

Bu bağlamda psikolojik sözleşme algılanan yükümlülüklerin karşılanması ile mükemmel bir karşlıklılık örneği sergilemektedir (Coyle-Shapiro ve Kessler, 2002, s. 72). Örneğin, standartlara göre yüksek ücret, kendini geliştirme fırsatları gibi kaynaklara ulaşabilen ve yüksek değer elde edebilen çalışanlar karşılıklıık normlarına uygun bir şekilde yükümlülük hissi ile örgütsel hedeflere ulaşılmasına ekstra-rol davranışları ve daha az devamsızlık göstererek katkı yapacaktır (Aselage ve Eisenberger, 2003, s. 492).

Adams tarafından geliştirilen eşitlik kuramı eşitsizlik algısının verimlilik üzerinde doğuracağı sonuçlara odaklanmıştır (Paşamehmetoğlu ve Yeloğlu, 2013, s. 154). Bireyler kendi performanslarını iş yerindeki akranlarının performansları ile kıyaslayarak, elde edilen kazanımlar açısından değerlendirmektedir. Bu değerlendirme esnasında birey esasen psikolojik sözleşmesini irdelemektedir (Paşamehmetoğlu ve Yeloğlu, 2013, s. 166).

Çalışanlar tutum ve davranışlarını belirlerken karşılıklı olarak yükümlülüklerin yerine getirilme derecesini değerlendirmektedir. Karşılıklı taahhütler üzerine kurulu bu mübadelede denge arayışı bulunmaktadır (Cihangiroğlu ve Şahin, 2010, s. 12). Çalışanlar eşitlik algısına inandığında psikolojik sözleşmeleri pekişmekte ve pozitif örgütsel tutum ve davranış geliştirmektedir. 
Teşvik katkı modelinde kişilerin bir işbirliği içerisine girdiklerinde menfaat çatışmasının ortaya çıktığından bahsedilebilir (Meydan ve Çetin, 2012, s. 152). Kuram açısından psikolojik sözleşmede taahhüt edilen teşvikler ve katkılar ile dağıtılan teşvikler ve katkılar söz konusudur (Lambert, 2011). March ve Simon (1958, s. 84) tarafından teşvik, örgütler tarafından herhangi bir fayda beklemeksizin çalışanlara yapılan ödemeler olarak tanımlanmaktadır. Örneğin ücret bir teşvik, yapılan iş ise bir katkıdır.

Lambert (2011, s. 695) ağırlıkıı olarak teşviklerin literatürde araştırıldığını belirtmektedir. Maalesef katkılar bir sonuç olarak değerlendirilmiştir. Hâlbuki model çalışanın katkısı ile örgüt tarafından verilen teşvikin karşılıklı değişimini öngörmektedir (Coyle-Shapiro ve Shore, 2007). Katkıların teşviklerin etkisi ile birlikte değerlendirilmesi daha uygun sonuçlar doğurabilir.

Nitekim, işgörenler örgüte katkıları ile örgütten aldıkları teşvikleri karşılaştırmaktadır. İşgören beklentisinin karşılığını alamadığını düşündüğünde dengeyi tekrar sağlayabilmek adına ellerinden geldikçe olumlu tutum ve davranışları azaltmaktadır (Coyle-Shapiro ve Kessler, 2000).

İşveren işgörenlerin menfaatini hesaba katmadığı takdirde güvene dayalı olmayan bir ilişki doğabilir, sonucunda da değişime direnci ve sinik davranışları beraberinde getirebilir (Cavanaugh ve Noe, 1999). Teşvik-katkı modelinde ilişki sürekli olmasına karşın çalışanın dengesizlik hissettiği anda söz konusu olumsuz davranışlar daha belirgin hal almaktadır (Coyle-Shapiro ve Shore, 2007).

Model taraflar açısından farklı bakış açıları sunmaktadır. Çalışan örgüt tarafından sunulan imkanın kendisi tarafından sağlanan katkıdan fazla olduğunu algıladığı zaman daha memnun olmaktadır (Coyle-Shapiro ve Shore, 2007). Örgüt açısından, çalışanların katkılarının örgüt tarafından imkan sunulmasını sağlayacak derecede olması yeterli görülmektedir. Lee ve arkadaşları (2011) da taraflar açısından farklılığı ortaya koymuş, işgören memnuniyeti ve algılanan katkının işverenin psikolojik sözleşme yükümlülüklerinde, işveren memnuniyeti ve algllanan teşvikin işgörenin yükümlülüklerinde değişiklik meydana getirdiğini tespit emiştir.

Bu modelde de bazı sorunlara cevap net olarak bulunamamaktadır. ilişkinin kimle kurulacağı hususu muğlaklılığını korurken, mütekabiliyet esasları ile değişime konu olan unsurların değeri belirlenmemiştir (Coyle-Shapiro ve Shore, 2007).

\section{Psikolojik Sözleşmenin Öncülleri ve Sonuçları}

Halihazırda işgörenlerin olumsuz tutum ve davranışlarını gerekçelendirmeye yönelik psikolojik sözleşme ihlallerinin üzerinde daha çok durulduğu görülmektedir. Ancak psikolojik sözleşme esasen çalışma ortamının bir çerçevesini sunmaktadır. İşveren-işgören arasındaki ilişkiyi açıklamakla psikolojik sözleşme işgörenlerin tutum ve davranışlarının da belirleyicisi olmaktadır. Diğer bir ifade ile çaış̧ma ortamında çalışanların sergilediği örgütsel tutum ve davranışlarının önemli belirleyicilerinden birisi de psikolojik sözleşme algısıdır (Schein, 1980). Bu açıdan öncül ve sonuçlarının ortaya konması ayrı bir öneme haizdir. Bu kısımda psikolojik sözleşmenin öncül ve sonuçları ele alınacaktır. 
Morrison ve Robinson (1997) bireysel özelliklerin çevresel faktörlerle birlikte kişisel algı ve değerlendirmeleri ne derecede etkilediğini çalışmıştır. Rousseau (1989)'ya göre psikolojik sözleşmenin öncüllerini çalışma öncesindeki deneyimler, stajyerlik dönemi ve işe başlandığında yaşanan ilk sosyalleşme süreci oluşturmaktadır.

Rousseau ve Trijowala (1998) konunun çok yönlü yapısını içerik, özellikler ve tatmin derecesi olmak üzere üç ayrı başlık altında toplamıştır. Guest (1998) çalışmasında psikolojik sözleşmeye sebep olan etkenleri örgüt kültürü, insan kaynakları uygulamaları, tecrübe, beklentiler ve alternatifler başlıkları altında toparlamaktadır.

Turnley ve Feldman (1998) kişilerin psikolojik sözleşmelerini şekillendiren beklentilerin üç ana kaynaktan doğduğunu öne sürmektedir. Bunlar, kendilerine örgüt temsilcileri tarafından verilen sözler, kendilerinin örgüt kültürünü nasıl algıladıkları ve kendilerinin örgütün işleyişine dair kişisel beklentileridir (Lester ve ark., 2002). Öte yandan, psikolojik sözleşmeye konu olan değişimin kaynağının kişisel olabileceği gibi bilgiye dayalı veya maddiyattan kaynaklı ya da saygı, sevgi ve hürmet gibi sosyo-duygusal faktör kaynaklı olabileceği bilinmektedir (Aselage ve Eisenberger, 2003, s. 491).

Psikolojik sözleşme teorisi çalışan başarııılı̆ıının ve düşük performansının temel belirleyicisi olarak örgütün vaatlerini yerine getirmemesini görmektedir (Aselage ve Eisenberger, 2003, s.492). Sonuç olarak işverenin davranışlarına cevaben çalışanlar da örgütsel tutum ve davranışlarını gözden geçirmektedir.

Bu anlamda, çalışanlara verilen vaatlerin yerine getirildiği örgütlerde görülebilir çıktılar arasında genellikle yüksek örgütsel bağlılık, pozitif örgütsel vatandaşlık davranışları ve düşük çalışan devir hızı ön plana çıkmaktadır. Freese ve Schalk (1996) ise psikolojik sözleşmenin olumlu olduğunun göstergesinin iş tatmini, verimlilik ve örgütte kalma niyeti olduğunu vurgulamaktadır.

Karşılıklılık ilkesi bağlamında örgütlerin çalışana verdiği taahhütleri yerine getirmekte zorlanması veya taahhütlerin çalışanlarca beklendiği şekilde tam olarak yerine getirilmemesi, çalışanın örgüte olan yükümlülüklerinde de bir düşüşe sebep olmaktadır (Aselage ve Eisenberger, 2003, s. 495).

Çalışan psikolojik sözleşmeye uyum konusunda bir sıkıntı yaşamadığı müddetçe örgütte gönüllü olarak kalmak ve örgüte katkı sağlamak istemektedir (Cihangiroğlu ve Şahin, 2010, s. 13). Öte yandan çalışanın psikolojik sözleşmeye uyulmadığı yönündeki algısı işten ayrılma niyetini artırmaktadır (Singh, 1998, s. 62).

Çalışmalar, psikolojik sözleşmeye uyulmasının örgütsel vatandaşlık (Robinson ve Morrison, 1995) ve örgütten ayrılma eğilimleri (Robinson ve Rousseau, 1994) ile ilişkili olduğunu göstermiştir (Lee ve ark., 2000). Rousseau (1995) tarafından işlemsel adalet algısı geliştiren çalışanların psikolojik sözleşmelerinin negatif davranışlar yapmamasına neden olduğu tespit edilmiştir.

Guest (1998) tarafından yapılan çalışmada ulaşılan sonuçlar; iş tatmini, örgütsel bağlıık, güvence sahipliği duygusu, iş ilişkileri, motivasyon, örgütsel vatandaşlık davranışları gibi verimliliği artan davranışların pozitif yönde, devamsızlık, işten ayrılma niyeti gibi verimliliği azaltan davranışların negatif yönde etkilendiğini göstermektedir. 
Aselage ve Eisenberger (2003, s. 497) sözleşme şartlarına uyulduğu takdirde çalışanın performansında gelişme gözlemlendiğini tespit etmiştir. Ancak, sözleşme kurallarının dışına çıkılması, yükümlülüklerin karşlıklı yerine getirilmemesi ihlaller oluşmasına neden olabilmektedir. Hemen hemen tüm çalışanların ihlal yaptığı bilinmektedir (Coyle-Shapiro ve Kessler, 2000).

İhlal algısı bir işgörenin işverenin kendisine karşı yükümlülüklerini yerine getirmediğini düşünmesidir (Morrison ve Robinson, 1997). Burada açıklık kazanması gereken husus yükümlülükler konusunun netlik kazanmasıdır. Yükümlülüklere örnek olarak işveren tarafından sağlanacak iş güvencesi ile terfilere karşılık işgörence geliştirilecek sadakat gösterilebilir (Rousseau, 1990, 1995). ìhlallerin neler olabileceği üzerine çalışma yapan Zuber ve Hammond (2002, s. 43)'e göre de taahhüt edildiği halde yerine getirilmeyenler konusunda aşağıda sıralanan bulgulara ulaşmıştır.

- $\quad$ Eğitim sözü verilmesi,

- Ücret ve ek faydalarda taahhüt edilen ile gerçekleşen arasındaki fark oluşması,

- Terfilerin söz verildiği gibi uygulanmaması,

- Işsin gereklerinin tam belirtilmemesi,

- İ̧ güvencesi ile ilgili söylenenden farklı uygulamalar yapılması,

- Geri bildirimler ve görüşlerin söylenenden çok farklı ve çok zayıf olması,

- Değişimin yönetilememesi,

- Taahhüt edilenden daha az sorumluluk verilmesi.

Ihlal algıları özellikle işgörenler açısından daha anlam kazanmakta ve ihanet duygularına varan güçlü duygusal tepkiler ortaya çıkabilmektedir. Rousseau (1989; 1990) ihlal algısının beklentilerin yerine getirilmemesinin duygusal bir sonucu olacağını, hayal kırıklığı ile sonuçlanacağını; diğer taraftan yükümlülüklerin yerine getirilmemesi durumunda ise karşılıklı güven duygularına zarar geleceğinden sözleşmeyi daha derinden sarsacağını öne sürmüştür (Thomas ve Anderson, 1998).

Morrison ve Robinson (1997) ihlal algısının sözleşme şartlarının gerçekten yerine getirilmemesinden kaynaklanabileceği gibi taraflar arasındaki yanlış algılamalar sonucunda da meydana gelebileceğini rapor etmiştir. Rousseau (1995) üçüncü bir sebep olarak da çevresel faktörleri düşünmüş ve tarafların engel olamayacağı sebeplerden kaynaklı bir ihlal yaşanabileceğini savunmuştur. Örneğin, Robinson ve Morrison (2000) çalışanların önceki işyerlerinde yaşadıkları ihlal algılarının mevcut işyerlerinde ihlal yaşama olasılı̆̆ını kuvvetlendirdiğini bulgulamıştır.

Psikolojik sözleşme sonucunda oluşan ihlaller; daha yüksek personel devir hızına; daha düşük seviyelerde güven, iş tatmini, bağ|ıık, örgütsel vatandaşlık davranışları ve tekrar bağlanma gibi sonuçlara yol açmaktadır. Psikolojik sözleşmenin ihlal edildiğini algılayan çalışan örgütsel bağılı̆̆ını 
azaltarak (Coyle-Shapiro ve Kessler, 2002), işverene duyulan güveni azaltarak (Robinson ve Rousseau, 1994), performanslarını düşürerek (Robinson, 1996), örgütsel vatandaşlık davranışları yapmayarak (Robinson ve Morrison, 1995) karşlık vermektedir.

Sözleşme ihlalleri negatif duygulara (Morrison ve Robinson, 1997), sözleşmelerin yeniden değerlendirilmesine (Robinson, Kraatz ve Rousseau, 1994; Coyle-Shapiro ve Kessler, 2002), örgüte duyulan güvenin azalmasına (Robinson, 1996) ve performans düşmesine (Robinson ve Morrison, 1995) neden olmaktadır.

\section{Psikolojik Sözleşmeye Yöneltilen Eleştiriler}

Her kavram için geçerli olan yanlışlama ilkesi ve eleştiriye açıklık psikolojik sözleşme için de geçerlidir. Bu açıdan çalışmanın bu kısmında psikolojik sözleşmeye yöneltilen eleştirile incelenmektedir. Anderson ve Schalk (1998) psikolojik sözleşme ile ilgili problemleri iki ana başlıkta toplamaktadır. Birincisi bireysel ve örgütsel seviyenin karşılaştırılmasında yaşanan problemler iken, ikincisi örgütü kimin temsil ettiği sorunudur.

Guest (1998) de benzer şekilde organizasyonu temsilen kimin sözleşme imzalayacağı konusunu dile getirmektedir. Bu konuda tartışmayı ilerleterek, organizasyon adına yetkin ve ehil olmayanların vaatleri sonucunda ihlallerin kaçınılmaz olduğunu savunmaktadır.

Rousseau (1998) çalışanların bir amir tarafından verilen sözü örgütün verdiği bir söz olarak algıladığını belirtmektedir. Benzer şekilde, Levinson (1965) da örgütün temsilcilerinin yaptığı faaliyetlerin kişisel değil örgütsel niyetin göstergesi olarak algılandığını ifade etmektedir. Bu durum işletmelerin sürekliliğini sağlayan ve görevleri içeren örgütsel politikalar, normlar ve kültürden kaynaklanmaktadır (Aselage ve Eisenberger, 2003, s. 493). Çünkü yetkililer temsil güçlerini, yasal, etik ve finansal sorumlulukları belirleyen örgütsel politikalar, normlar ve kültürden almaktadır.

Rousseau (1990) bu iki problemi yenmek açısından, psikolojik sözleşmeye işgören ile işveren arasındaki ilişkinin bireyin karşılıklı yükümlülükler hakkındaki inançları şeklinde bir tanım getirmektedir. Böylelikle, bakış açısı da iki farkı seviye arasındaki ilişkiden tek taraflı bireysel seviyeye kaymıştır. Psikolojik sözleşme öznel, bireysel bir algı şekline bürünmüştür. Yani, karşılıkı ilişkilerin bireysel olarak nasıl algılandığı ön plana çıkmıştır. Örgütlerin yükümlülüklerini yerini getirmede bireysel farklılıklar değer kazanmıştır.

Ancak organizasyonu kimin temsil edeceği problemine çözüm olarak tek taraflı bireysel algılayışı öneren Rousseau ve diğer araştırmacılar, psikolojik sözleşmenin çıkış noktası ve temeli olan karşılıklı bir anlaşma oluşunu göz ardı etmektedir. Bu durum kavramsal bir tartışma doğurmaktadır.

Bu terimi ilk kullanmaya başlayanlar psikolojik sözleşmeyi sezgisel bir araç olarak tasarlamıştır. Analitik bir yapıya büründürmeye çalışmamıştır. Artan ilgi ile görgül çalışmalarda görülen ilerleme psikolojik sözleşmede kavram kargaşasına yol açmıştır. Diğer örgütsel psikoloji veya davranış kavramlarından farkının ortaya konması gerekmektedir. İş tatmini veya örgütsel bağlılıktan farklı yanları, eşitlik ve sosyal mübadele teorileri ile benzerlikleri açıklanabilmelidir. 
Guest (1998) de psikolojik sözleşmenin iş tatmini ve bağlılık gibi örgüt psikolojisi konularından farklııı̆ının sözleşme taraflarından ziyade aradaki ilişkinin öneminden kaynaklandığını ifade etmektedir. Psikolojik sözleşmedeki taraflar arasındaki ilişkide taraflardan birisinin ilgi sahası belirli iken diğerininki belirsizdir. Rousseau (1998)'ya göre de psikolojik sözleşmelerin hangi koşullar altında oluştuğu belirsizliğini korumaktadır. Bir diğer belirsizlik de uygulama sürecinde psikolojik sözleşmede taraflardan sadece birisi keyfiyeten ya da haber vermeksizin değişiklik yapabilmektedir (Guest, 1998, s.652).

Diğer bir eleştiri konusu ise psikolojik sözleşme kavramının literatürde kabul görmesine ilişkindir. Abrahamson (1996) moda yönetim konuları arasında iş zenginleştirme, süreç mühendisliği ve kalite çemberlerini sayarak, psikolojik sözleşmenin de bu türden bir uygulama olabileceğini tartışmaktadır.

Rousseau (1990)'nın önermelerine getirilebilecek bir eleştiri de kariyer isteklerindeki değişimi hesaba katmadığı yönündedir. Guest (1998)'e göre psikolojik sözleşme konusundaki çalışmalar yeni olduğu için içeriğindeki değişikliklerle ilgili de çok az bulgu bulunmaktadır.

Bu konuda Arnold (1996, s. 514) tarafından öne sürülen diğer bir sorunsal ise psikolojik sözleşmenin ölçümü ile ilgilidir. Araştırmacı beklentilerin ölçümü ile mütekabiliyetin ölçümünün eşdeğer olamayacağına vurgu yapmaktadır.

Sonuç olarak psikolojik sözleşmeye yöneltilen eleştiriler içerik geçerliği, yapısal geçerlik ve test edilebilirlik ve uygulanabilirlik şeklinde üç temel esas çerçevesinde ele alınabilir. Bu kapsamda literatürde cevabı aranmaya devam edecek konuları aşağıdaki şekilde özetlemek mümkündür.

- Kavramın İçerik geçerliği

○ Psikolojik sözleşme beklentilerle mi, vaatlerle mi ya da yükümlülüklerle mi ilgilenmektedir?

○ Bu beklenti, vaat veya yükümlülüklerin kesin içeriği belirli midir?

○ Örgütsel popülasyonlar arasında ve hatta içerisinde psikolojik sözleşmenin içeriği istikrarlı mıdır?

- Kavramın yapısal geçerliği

- Anlaşmanın temelinden yoksunluğuna bağlı olarak hukuki metafordan kolay olmayan yolla tercüme edilmiştir.

○ Organizasyonu kimin temsil ettiği veya organizasyonun ne olduğu açık değildir.

- Boyutları çalışılsa da tam olarak ortaya konmamıştır.

- Psikolojik sözleşmenin test edilebilirliği ve uygulanabilirliği 
○ Psikolojik sözleşmenin nasıl kurulduğu ve nasıl değiştirileceği belirli değildir.

○ Baskın olan Kuzey Amerika yazınında açıkça ifade edilen vaatlere yer verilmiştir. Üstü kapalı verilen sözlerin ifadesi kolay değildir.

○ Psikolojik sözleşmenin sınırları tespit edilmemiştir.

\section{Olası Tartışma Alanları ve Sonuç}

Yazında artan bir şekilde psikolojik sözleşme konusuna ilgi görülmektedir. Bu artan ilgi sonucunda; yapıları açıklama çabalarında artma görülmüş, karmaşık görgül çalışmaları daha anlaşılır hale getirme yönünde adımlar atılmış, çok çeşitli sorular ile açıklayıcı olunmaya başlanmış, yenilikçi kavramsal modeller üretilmiş ve güvenirlik ve geçerlik açısından karşılaşılan güçlükler yenilmeye çalışımıştır.

Yazında daha önce psikolojik sözleşme konusunda yapılmış çalışmaların ortaya koyduğu sonuçlar genel olarak sıralanacak olursa, aşağıdaki bulgulara ulaşılabilir.

- Psikolojik sözleşme algısı tamamen özneldir.

- Psikolojik sözleşme algısı dinamiktir.

- Bağlamsal ve çevresel faktörlerden etkilendiği gibi, bireysel faktörler de etkili olmaktadır.

- Psikolojik sözleşmeler mütekabiliyete dayalı gelişmektedir.

- Psikolojik sözleşmenin örgütsel tutum ve davranışları açıklamadaki rolü bütüncül bir yaklaşımla ortaya konulamamıştır.

Sonuç olarak pozitif, huzurlu ve barış̧ıl bir çalışma ortamı hem işgören hem işveren açısından aranmakta ve yaratılmaya çalışımaktadır. Pozitif çalışma ortamından kastedilmek istenen, çalışanlardan makul taleplerde bulunmak ve yönetilebilir bir iş yükü dağılımı yapmak, çalışana işi üzerinde kişisel kontrol alanı bırakmak, çalışan olarak akranlarından ve amirlerinden destek görmek, çalışma ortamında pozitif arkadaşlık ilişkileri yaşamak, makul ve net görev tanımlarına sahip olmak ve katıIımcı yaklaşım içerisinde kurum politikalarına katkı sağlamaktır.

Ancak böyle bir ortamın süreklilik kazanabilmesi, örgüt kültürü haline gelebilmesi için işveren ve işgören açısından karşılıklı beklenti ve yükümlülüklerin gerçekleşmesi temel esastır. Başka bir ifade ile işveren-işgören ilişkisinde psikolojik sözleşme ilişkisel bir temele dayalı gelişirse varlığı bilinen ancak bir türlü hayata geçirilemeyen pozitif, huzurlu ve barışçıl bir çalışma ortamından söz edebilmek mümkün olacaktır.

Ancak, ulusal yazın bağlamında psikolojik sözleşme son on yıl içerisinde telaffuz edilmeye başlanmış ve bazı çalışmalara konu edilmiştir. Ne var ki ulusal yazında giderek artan bir ilgi gören psikolojik sözleşme konusunda yeterli ulusal kaynak bulunamamaktadır. Diğer yandan ağırlıklı olarak görgül çalışmalar yapıldığı görülmektedir. Bu kapsamda akademik çalışmaların kuramsal tartışmalara 
yönlendirilmesi noktasında bu çalışmanın katkı sağlaması beklenmektedir. Çünkü psikolojik sözleşme kavramını bütüncül bir bakış açısı ile ele alan, alanın nereye doğru gittiğini tartışan, muhtemel araştırma alanlarını ortaya koyan bu çalışmanın alandaki bu boşluğu dolduracağı düşünülmektedir. Ayrıca, psikolojik sözleşme literatürüne bütüncül bir yaklaşımla bileşenleri, özellikleri, öncülleri ve sonuçları açısından bir gözden geçirme niteliği taşıyan bu çalışmanın araştırmacı ve uygulamacılara ışık tutması da beklenmektedir. Ancak kavramsal olarak ele alınan bu çalışma neredeyse tamamen yabancı kaynaklardan yararlanılarak hazırlanmıştır. Bu anlamda ulusal çalışmalara katkı sağlanmakla birlikte toplumsal kültürün etkisini yansıtmakta yetersiz kalınmaktadır.

Öte yandan bu kavramsal çalışma ile gerek akademik gerekse iş dünyası açısından önemli görülen işveren-işgören ilişkisinin temelini oluşturan psikolojik sözleşme yaklaşımı aydınlatılmaya çalışılmıştır. Örgütsel tutum ve davranışların belirleyicisi olan psikolojik sözleşmenin yönetilmesi insan kaynakları yönetimi açısından psiko-sosyal bir risk faktör oluşturmaktadır. İnsan kaynakları uygulamalarında psikolojik sözleşme yaklaşımdan faydalanılması işgücü verimliliğini artırabileceği gibi örgütsel kültür, örgütsel değişim ve kurumların yeniden yapılandırılması çalışmalarında kolaylık da sağlayabilir. İnsan kaynakları yöneticileri başta olmak üzere yöneticiler psikolojik sözleşmeleri yönetebildiği sürece pozitif çalışma ortamı yaratabilecektir.

Bunlarla birlikte işverenin temel gayesi olan büyüme ve verimlilikte beşeri sermayenin daha etkin, etkili ve yeterli bir şekilde kullanılabilmesi için psikolojik sözleşmelerin yönetilebilmesi ön plana çıkmaktadır. Sürdürülebilir rekabet avantajı sağlamak isteyen işletmelerin adaptif performans göstererek çevreye uyum sağlayabilmeleri için işgörenlerin psikolojik sözleşmelerinin anlaşılması ve yönetilebilmesi gerekmektedir.

Bu açıdan akademik çalışmalarla ele alınması muhtemel konulardan bazılarına aşağıda değinilmektedir. Psikolojik sözleşme kavram olarak incelenirken, özellikle güncel yaklaşımlarda, bireysel algılara yoğunlaşılmış olmasına karşın, görgül araştırmalar kişilik ile psikolojik sözleşme arasındaki ilişkiye değinmemiştir. Hâlbuki psikolojik sözleşme tanımı gereği birey seviyesinde gerçekleşmektedir. Kişilik özellikleri aynı zamanda psikolojik sözleşmelerin uygulanmasında da devredir. Çünkü kişilik örgütsel tutum ve davranışların da bir belirleyicisidir. Böylelikle dinamik bir yapısı olan psikolojik sözleşmeyi kişilik özellikleri zamanla şekillendirebilmektedir. Bu nedenle, kişisel farklııkların çalışıması ve psikolojik sözleşmenin kişilikle ilişkilendirilmesi gerekmektedir. Bireysel faktörler olarak kişilik özellikleri ile birlikte öz güven, kontrol odağı, öz yeterlilik ve negatif duygusallık gibi kişisel özellikler araştırılmaya muhtaç konular olarak durmaktadır.

Alanyazında psikolojik sözleşme algısının ağırlıklı olarak işgören açısından incelendiği görülmektedir. Halbuki öznel bir yapısı olan psikolojik sözleşme karşılıklı beklenti ve yükümlülüklerden oluşmaktadır. Bu nedenle, örgütsel problemler çalışan perspektifi ve yönetici perspektifi olmak üzere iki açıdan ele alınabilir. Böylelikle, aynı örneklem içerisinde işverenin de algılarının ölçülmesi katkı sağlayıcı olabilir ve psikolojik sözleşmenin açıklanamayan kısımlarına ışık tutabilir. 
Psikolojik sözleşme çalışmaları tek bir örgütte yürütülebileceği gibi daha genellenebilir sonuçlar için çeşitli büyüklüklerde değişik örgütlerde de uygulanabilir. Örneğin, benzer vasıflarda elemanlara sahip olan KOBi'ler örneklem olarak tercih edilebilir. Ancak sektörel farklııklardan dolayı farklı nitelikteki çalışanlar değişik türlerde ve boyutlarda psikolojik sözleşme geliştirebilir. Bu sebeple bu alanda çalışacak araştırmacılar örneklem olarak belirli meslek grupları veya belirli sektörleri tercih edebilir. Kamu çalışanlarının araştırma konusu yapılması psikolojik sözleşme alanındaki tartışmalara katkı yapabilir.

Önerilebilecek diğer bir alan ise örgütlerin karanlık yüzü olarak atfedilen ve üretkenliği azaltıcı davranışlar şeklinde karşılaşılan sabotaj, devamsızlık, suiistimal, yolsuzluk ve hırsızlık gibi etik olmayan hareketler araştırılarak psikolojik sözleşmelerin bu kapsamdaki rolü ortaya konabilir.

Bunlarla birlikte olsa çalışmaların önündeki kısıtlardan en belirgin olanı veri toplanmasında karşılaşılacak sosyal beğenirlik etkisidir. Katılımcıların mevcut durumlardan ziyade ideali yansıtma eğilimleri sağ|ıklı verilerin elde edilmesini engelleyebilir. Ayrıca çalışmalar için kısıt olabilecek diğer bir husus da metriklerin sadece uygulama anındaki düşünceleri ölçmesidir. Halbuki dinamik yapısı nedeniyle psikolojik sözleşme sürekli değişkenlik gösterebilmektedir. Bu maksatla deneysel ve boylamsal çalışmalarla alanyazına daha fazla katkı sağlanabilir.

\section{Kaynaklar}

Abrahamson, E. (1996). “Management fashion”, Academy of Management Review, 21, 254-85.

Anderson, N. Ve Schalk, R. (1998). “The psychological contract in retrospect and prospect”, Journal of Organizational Behavior, 19, 637-647.

Argyris, C.P. (1960). Understanding Organizational Behavior, Homewood, IL, s. Dorsey Press.

Arnold, J. (1996). "The psychological contract, s. A concept in need of closer scrutiny", European Journal of Work and Organizational Psychology, 5 (4), 511-520.

Aselage, J. Ve Eisenberger, R. (2003). "Perceived Organizational Support and Psychological Contracts, s. A Theoretical Integration", Journal of Organizational Behavior, 24, 491-509.

Blau, G. (1988). "Testing Generalizability of A Career Commitment And Its Impact On Employee Turnover", Journal of Vocational Behavior, 35, 88-193.

Cavanaugh, M.A. ve NOE, R.A. (1999). "Antecedents and consequences of relational components of the new psychological contract", Journal of Organizational Behavior, 20, 323-340.

Cihangiroğlu, N. ve Şahin, B. (2010). “Organizasyonlarda Önemli Bir Fenomen, s. Psikolojik Sözleşme”, ZKÜ Sosyal Bilimler Dergisi, Cilt 6, Sayı 11, 1-16.

Coyle-Shapiro, J. ve Kessler, I. (2000). "Mutuality, stability and psychological contract breach, s. A longitudinal study", Paper presented at the annual meeting of the Academy of Management, Toronto, Canada, 04-09 Ağustos. 
Coyle-Shapiro, J.A.-M ve Kessler, I. (2002). "Exploring Reciprocity Through the Lens of the Psychological Contract, s. Employee and Employer Perspectives", European Journal of Work and Organizational Psychology, 11 (1), 69-86.

De Cuyper, N., Rigotti, T., De Witte, H. ve Mohr, G. (2008). "Balancing Psychological Contracts, s. Validation of a Typology", The International Journal of Human Resource Management, Vol. 19, No. 4, 543-561.

Freese, C. ve Schalk, R. (1996). "Implications of Differences in Psychological Contracts for HRM", European Journal of Work and Organizational Pscyhology, 5 (4), 501-509.

Gouldner, A.W. (1960). "The Norm of Reciprocity, s. A Preliminary Statement", American Sociological Review, 25, 161-178.

Guest, D.E. (1998). “Is the Psychological Contract Worth Taking Seriously?” Journal of Organizational Behavior, 19, 649-664.

Homans, G. (1961). Social Behavior, s. Its Elementary Forms. New York, s. Harcourt Brace.

Kiss, G.D. (1994). “The New Employment Contract”, Human Resource Management, Vol. 33, Number 3, 335-352.

Kotter, J.P. (1973). “The psychological contract”, California Management Review, 15, 91-99.

Lambert, L.S. (2011). “Promised and Delivered Inducements and Contributions, s. An Integrated View of Psychological Contract Appraisal”, Journal of Applied Psychology, Vol. 96, No. 4, 695712.

Lee, C., Liu, J., Rousseau, D.M., Hui, C. ve Chen, Z.X. (2011). "Inducements, Contributions, and Fulfillment in New Employee Psychological Contracts", Human Resource Management, Vol. 50, No. 2, 201-226.

Lester, S.W., Turnley, W.H., Bloodgood, J.M. ve Bolino, M.C. (2002). "Not seeing eye to eye, s. Differences in supervisor and subordinate perceptions of and attributions for psychological contract breach," Journal of Organizational Behavior, 23, 39-56.

Levinson, H. (1962). Men, Management and Mental Health, Cambridge, MA, S.

March, S.G. ve Simon, H.A. (1958). Organizations, Wiley, New York, 1958.

Meydan, C.H. ve Çetin, F. (2012). "Vekalet Kuramı", Sözen, H. Cenk ve Basım, H.Nejat, Örgüt Kuramları, 2.Baskı, İstanbul, Beta Yayınları, 141-161.

Morrison, D.E. (1994). “Psychological Contracts and Change”, Human Resource Management, Vol. 33, Number 3, 353-372. 
Morrison, E.W. ve Robinson, S.L. (1997). "When Employees Feel Betrayed, s. A Model of How Psychological Contract Violation Develops", The Academy of Management Review, Vol. 22, No. 1, 226-256.

Nelson, D.L. ve Quick, C. (1999). Organizational Behavior, s. The Essentials, West Group.

Nicholson, N. ve Johns, G. (1985). The absence culture and the psychological contract - Who's in control of absence?Academy of Management Review, 10, 397-407.

Paşamehmetoğlu, A. ve Yeloğlu, H.O. (2013). “Motivasyon”. İçinde, s. Der. Sığrı, Ü. ve Gürbüz, S. Örgütsel Davranış. İstanbul, Beta Yayınları, 137-174.

Patrick, H.A. (2008). "Psychological Contract and Employment Relationship", The Icfai University Journal of Organizational Behavior, Vol. VII, No. 4, 7-24.

Porter, L.W., Pearce, J.L., Tripoli, A.M. ve Lewis, K.M. (1998). "Differential perceptions of employers' inducements, s. implications for psychological contracts", Journal of Organizational Behavior, 19, 769-782.

Purvis, L.J. ve Cropley, M. (2003). "The psychological contracts of National Health Service nurses", Journal of Nursing Management, 11, 107-120.

Raja, U., Johns, G. ve Ntalianis, F. (2004). "The Impact of Personality on Psychological Contracts”, Academy of Management Journal, Vol. 47, No. 3, 350-367.

Robinson, S. L. (1996). "Trust and breach of the psychological contract", Administrative Science Quarterly, 41, 574-599.

Robinson, S.L., Kraatz, M.S. ve Rousseau, D.M. (1994). “Changing Obligations And The Psychological Contract, s. A Longitudinal Study," Academy of Management Journal, Vol. 37, No. 1, 137-152.

Robinson, S.L ve Morrison, E.W. (1995). "Psychological Contracts and OCB, s. The. Effect of Unfulfilled Obligations on Civic Virtue Behavior", Journal of Organizational Behavior, Vol. 16, No. 3, 289-298.

Robinson, S.L. ve Morrison, E.W. (2000). "The development of psychological contract breach and violation, s. a longitudinal study," Journal of Organizational Behavior, 21, 525-546.

Robinson, S.L. ve Rousseau, D.M. (1994). "Violating the psychological contract, s. not the exception but the norm," Journal of Organizational Behavior, Vol. 15, 245-259.

Rousseau, D.M. (1989). "Psychological and implied contracts in organizations", Employee Rights and Responsibilities Journal, 2, 121-139.

Rousseau, D.M. (1990). “New hire perceptions of their own and their employer's obligations, s. A Study of psychological contracts", Journal of Organizational Behavior, 11, 389-400. 
Rousseau, D.M. (1995). Psychological Contracts in Organizations, s. Understanding Written and Unwritten Agreements. Thousand Oaks, CA, Sage Publications.

Rousseau, D.M. (1996). "Changing the Deal While Keeping People", Academy of Management Executive, Vol.10, No.1, 50-56.

Rousseau, D.M. (1998). "Why Workers Still Identify with Organizations," Journal of Organizational Behavior, Vol. 19, No. 3, 217-233.

Rousseau, D.M. (2001). Schema, Promise and Mutuality, s. The Building Blocks of Pyschological Contract. Journal of Occupational and Organizational Pyschology, 74, 511-541.

Rousseau, D.M. ve Parks, J.M. (1993). “The contracts of individuals and organizations”, Research in Organizational Behavior, 15, 1-43.

Rousseau, D.M. ve Tijoriwala, S.A. (1998). “Assessing psychological contracts, s. Issues, alternatives and measures", Journal of Organizational Behavior, 19, 679-695.

Rousseau, D.M. ve Wade-Benzoni, K.A. (1994). "Linking Strategy and Human Resource Practices, S. How Employee and Customer Contracts Are Created", Human Resource Management, Vol. 33, Number 3, 463-489.

Schein, E. (1965). Organizational Psychology, Oxford, England, s. Prentice-Hall.

Schein, E. (1978). Career Dynamics, Reading, MA, s. Addison-Wesley.

Schein, E. H. (1980). Organizational Psychology, 3rd Edition, New Jersey, s. Prentice-Hall.

Schneider, B. (1990). Organizational climate and culture. Pfeiffer.

Sels, L., Janssens, M. ve Van Den Brande, I. (2004). "Assessing the Nature of Psychological Contracts, s. A Validation of Six Dimensions", Journal of Organizational Behavior, 25, 461-488.

Singh, R. (1998). "Redefining psychological contracts with the U.S. Work force, s. A critical task for strategic human resource management planners in the 1990s", Human Resource Management, Vol. 37, No. 1, 61-69.

Thomas, H.D. ve Anderson, N. (1998). "Changes in newcomers' psychological contracts during organizational socialization, s. A study of recruits entering the British Army," Journal of Organizational Behavior, 1998, 19, 745-767.

Turnley, W.H. ve Feldman, D.C. (2000). "Re-Examining the Effects of Psychological Contract Violations, s. Unmet Expectations and Job Dissatisfaction as Mediators", Journal of Organizational Behavior, Vol. 21, No. 1, 25-42.

Wellin, M. (2007). Managing the Psychological Contract, s. Using the Personal Deal to Increase Performance, Ingiltere, s. Gower Publishing Limited. 
Zhao, H., Wayne, S.J., Glibkowski, B.C. ve Bravo, J. (2007). "The Impact of Psychological Contract Breach On Work-Related Outcomes, s. A Meta-Analysis”, Personnel Psychology, 60, 647-680.

Zuber, T.J. ve Hammond, J.B. (2002). "The Psychological Contract, s. Retaining Newly Employed Physicians", The Physician Executive, May/June, 40-43. 
